\title{
STRUCTURAL FEATURES AND EMPLACEMENT OF THE LATE SVECOFENNIAN PERNIÖ GRANITE SHEET IN SOUTHERN FINLAND
}

\author{
OLAVI SELONEN, CARL EHLERS and ALF LINDROOS
}

OLAVI SELONEN, CARL EHLERS and ALF LINDROOS, 1996: Structural features and emplacement of the late Svecofennian Perniö granite sheet in southern Finland. Bull. Geol. Soc. Finland 68, Part 2, 5-17.

The 1840-1830 Ma old Perniö granite occupies the southern margin of the Sauvo-Perniö granite area located in the western part of the late Svecofennian granite-migmatite zone in southern Finland. The S-type Perniö granite is light to dark red, medium- to coarse-grained with euhedral K-feldspar phenocrysts forming the porphyritic texture of the granite.

The high grade supracrustal volcanic rocks and mica gneisses in the Sauvo-Perniö granite area show polyphase deformation. The D1 is characterized by isoclinal and intrafolial F1 folds. During the D2 the supracrustal sequence was thrusted towards the northwest. Combined ductile E-W shear movements and NNW-SSE compressional movements defined a transpressional tectonic regime during the $\mathrm{D} 3$ deformation.

The Perniö granite intruded along subvertical mid-crustal feeder channels and was emplaced as a sheet or sheets along subhorizontal shear zones during the late stage of the F3 folding. After intruding into the shear zones the viscous granite magma was deformed. The K-feldspar phenocrysts in the granite acted as rigid particles in a viscous matrix and were rotated and imbricated in response to shearing along the subhorizontal shear zones indicating movements of the upper side of the granite sheet towards the west. Strike-slip dilatancy pumping is suggested as a possible mechanism for the emplacement of the Perniö granite.

Key words: granites, phenocrysts, gneisses, structural analysis, deformation, folds, shear zones, emplacement, dilatancy, Paleoproterozoic, Perniö, Kemiö, Finland.

Olavi Selonen, Carl Ehlers and Alf Lindroos: Åbo Akademi University, Department of geology and mineralogy, FIN-20500 Turku, Finland. E-mail: olavi.selonen@abo.fi; carl.ehlers@abo.fi; alf.lindroos@abo.fi 


\section{INTRODUCTION}

The Palaeoproterozoic Svecofennian domain in southern Finland is characterized by extensive late Svecofennian potassium granites with $\mathrm{U}-\mathrm{Pb}$ zircon ages around 1840-1830 Ma. The granites occur as a distinct zone along the southern coast of Finland: the late Svecofennian granite-migmatite zone (LSGM-zone, Ehlers et al. 1993). The zone extends from the archipelago in southwestern Finland to southeastern Finland and is roughly $100 \mathrm{~km}$ wide (Fig. 1).

The late Svecofennian potassium granites are found within the LSGM-zone as large magmatic porphyritic granites (eg. the Perniö granite) and as large heterogeneous migmatitic granite complexes covering several hundred square kilometres, as well as small even-grained granites occupying a few dozen square kilometres. The large porphyritic granites have intruded as semi-concordant sheets between gently dipping tectonically imbricated slabs of high grade metamorphic rocks, while the small granite intrusions are emplaced as balloons and dykes sometimes cutting the subhorizontal host rocks (Ehlers et al. 1993). The migmatite granites are composed of in situ granitic melts. Despite the structural differences, all the late Svecofennian granites seem to belong to the same 1840-1830 Ma age group (Suominen 1991; Ehlers et al. 1993).

The gently dipping Perniö granite sheet is situated in the western part of the LSGM-zone (Fig. 1). Previously the granite has been briefly mentioned by the authors in connection with the description of the LSGM-zone in Ehlers et al. (1993). Selonen (1994) has studied the granite as a potential site for dimensional stone. In this paper we will give a detailed description of the structural characteristics of the Perniö granite and discuss its emplacement.

\section{GEOLOGICAL OUTLINE}

The conspicuous lozenge-shaped Sauvo-Perniö granite area in the western part of the
LSGM-zone (Fig. 1) consists of heterogeneous subhorizontal late Svecofennian granites and migmatites intruding early Svecofennian subhorizontal supracrustal rocks and granodiorites (Fig. 1). The porphyritic Perniö granite occupies the southern margin of this area (Fig. 1). The early supracrustal rocks include mica gneisses and quartz-feldspar schists intercalated with basaltic pillowed lavas and marbles. The sequence is strongly deformed and lies in a subhorizontal position with a transposed layering parallel to the schistosity. The 1.89-1.88 $\mathrm{Ga}$ old early Svecofennian granodiorites intruded the supracrustals mainly as subparallel sheets along the schistosity and were subsequently deformed during the continuing deformation.

The supracrustal rocks and the granodiorites are metamorphosed under high grade conditions, which is shown by the growth of garnets and pyroxenes and by abundant anatexis. The intrusions of the late potassium granites, ca 1.84-1.83 Ga ago, were closely connected to this high grade metamorphism and geographically define the LSGM-zone in the southern Finland. For details of the high grade metamorphic rocks in the western parts of the LSGM-zone see Schreurs 1985, Hölttä 1986, Van Duin 1992 and Väisänen et al. 1994.

\section{THE PERNIÖ GRANITE}

The Perniö granite (Eskola 1914) is distinguished from the rest of the granites in the Sauvo-Perniö granite area by its porphyritic and relatively homogeneous appearance. The east-westerly elongated granite body covers ca $400 \mathrm{~km}^{2}$. It is divided by the Halikko bay into two subareas: the western Kemiö area and the eastern Perniö area (Fig. 1). In Kemiö the granite is ca $8 \mathrm{~km}$ wide in N-S direction, while it in Perniö reaches further north and is ca $20 \mathrm{~km}$ wide (Fig. 1).

The Perniö granite is porphyritic, medium- to coarse-grained with large (up to $5 \mathrm{~cm}$ long) K-feldspar phenocrysts. The intensity of the 


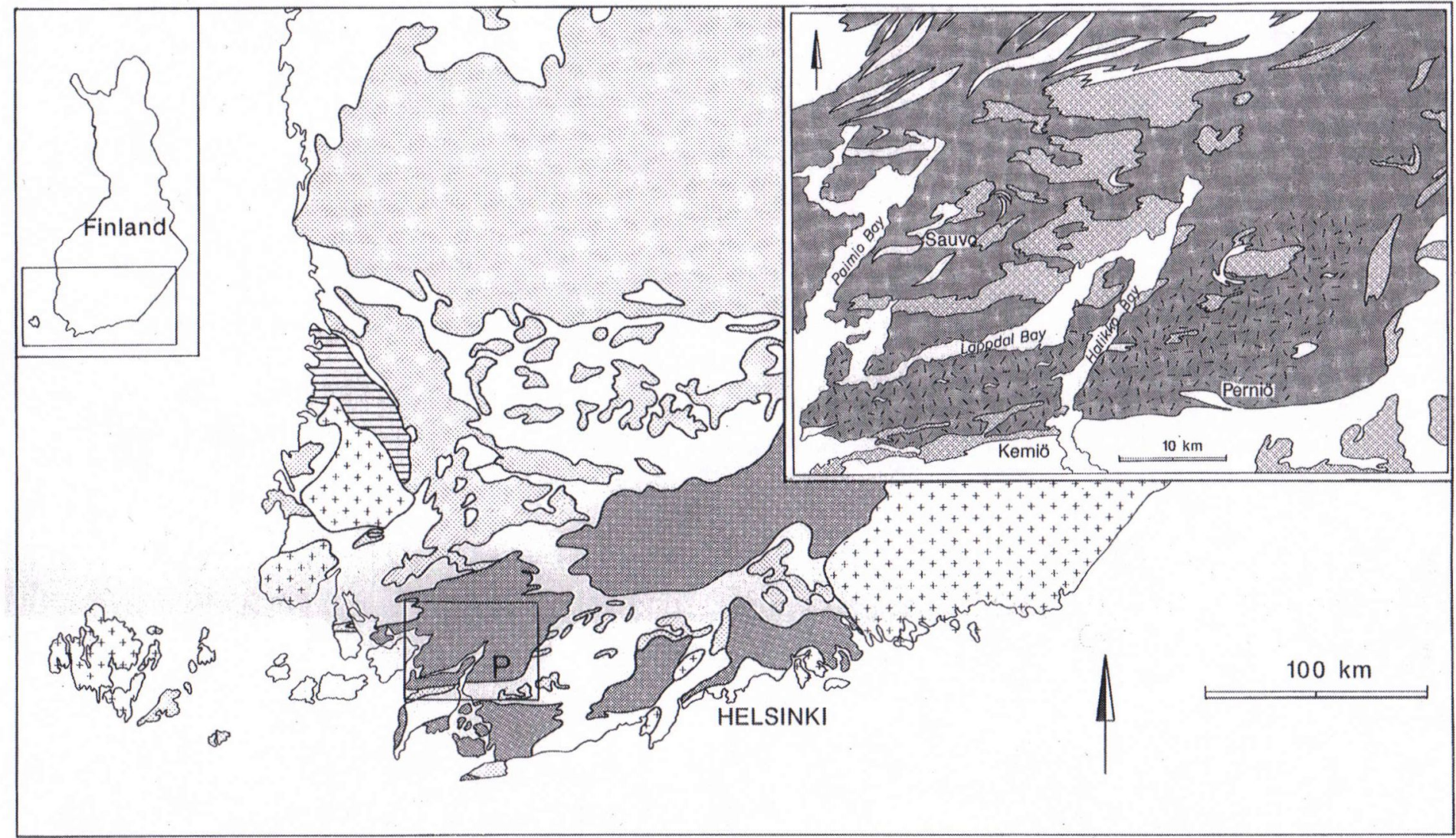

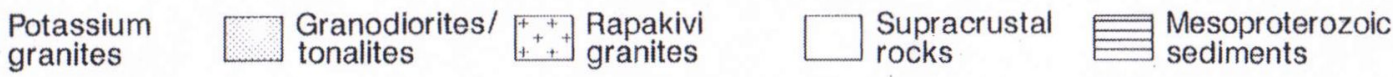

Figure 1. Geological outline of southern Finland. The potassium granites define the late Svecofennian granite-migmatite (LSGM) zone along the southern coast. After Simonen (1980). P=Perniö. Inset shows the main geological features in the Sauvo-Perniö granite area. The stippled area indicates the extension of the Perniö granite. The inset map is based on Härme (1960) and observations by the authors. 
foliation and lineation varies and massive homogeneous parts can be found. The colour of the granite varies from light to dark red. The main minerals in the granite are potassium feldspar, quartz, plagioclase, chloritic biotite and clusters of garnet. Muscovite, zircon and apatite are found as accessories. Closely packed euhedral phenocrysts of potassium feldspar form the porphyritic texture of the granite.

The Perniö granite is characterized by a high $\mathrm{K}_{2} \mathrm{O}$ content (6-7 \%), low $\mathrm{MgO}$ (ca 0,3\%) and $\mathrm{CaO}$ (ca $1 \%$ ) contents and is of S-type. The $\mathrm{SiO}_{2}$ content is ca $74 \%$ and the $\mathrm{Al}_{2} \mathrm{O}_{3}$ content is 13-14 \% (Eskola 1914 and analyses by the authors).

Suominen (1991) lists four U-Pb zircon ages from different parts of the Perniö granite body: $1840 \pm 8 \mathrm{Ma}$ in the Kemiö area, and $1840 \pm 8 \mathrm{Ma}$, $1829 \pm 14 \mathrm{Ma}$ and $1829 \pm 14 \mathrm{Ma}$ in the Perniö area.

Aplites and pegmatites occur in the Perniö granite as subvertical and subhorizontal dykes. The subvertical aplite dykes are sharply crosscutting varying in width from 10 to $40 \mathrm{~cm}$, whilst the subhorizontal dykes appear as irregular bodies. The subvertical pegmatite dykes are $10-15 \mathrm{~cm}$ in width and the subhorizontal dykes are exposed as irregular pods.

The Perniö granite contains biotite rich patches and schlieren, ca $5 \mathrm{~cm}$ in width. Inclusions of older supracrustal and infracrustal rocks normally occur as sharp-edged fragments emphasizing the intrusive character of the granite. It is quite homogeneous in the Perniö area, while supracrustal fragments and strips are more abundant in the Kemiö area.

\section{Contacts}

At the southern contact against the supracrustals in the Perniö area, the Perniö granite is often intensely foliated and strongly sheared in E-W direction. The gneisses at the contact are migmatitic and veined with coarse-grained granite leucosomes, which decrease in abundance southwards, away from the contact.
The schistosity in the gneisses strike E-W and dip steeply $\left(80^{\circ}\right)$ to the south (Fig. 2).

In the Kemiö area, the Perniö granite is bordered by granodiorite, but the contact is not exposed. The foliation in the granodiorite strikes $\mathrm{E}-\mathrm{W}$ and dips in the eastern parts ca $60^{\circ}$ and in the western parts $20-40^{\circ}$ to the south (Fig. 2).

Northwards in the Kemiö and the Perniö areas, the Perniö granite grades into a heterogeneous migmatite granite. The western contact is sharp and marked by a regional steeply dipping shear and fault zone (Fig. 2), whilst towards the east the granite grades into a heterogeneous medium-grained migmatitic potassium granite.

The subhorizontal footwall contact between the gently dipping supracrustals and the sheet-like Perniö granite is exposed in the southern parts of the Kemiö area. On the contact planes the supracrustals show a strong, gently dipping (0-30 eastwards) stretching lineation.

\section{STRUCTURAL FEATURES}

Three deformational phases have been identified by observed macroscopic overprinting relations and by microscopic studies: D1, D2 and D3. The deformation phases from D1 to D3 are seen in the supracrustals, whilst the Perniö granite has recorded only D3 structures.

\section{Structures in the older gneisses}

Due to the high metamorphic grade, primary sedimentary structures are sparse in the area. In some mica gneisses and quartz-feldspar schists a banding can be observed. It can be interpreted as a rest of a layering (S0). The oldest deformational phase (D1) observed is defined by isoclinal, intrafolial and rootless F1 folds. The rare F1 folds can be distinguished from the F2 and F3 folds on the basis of a well developed penetrative $\mathrm{S} 1$ axial plane schistosity. The sparse F1 folds can be seen eg. in the northern parts of the Kemiö area. 


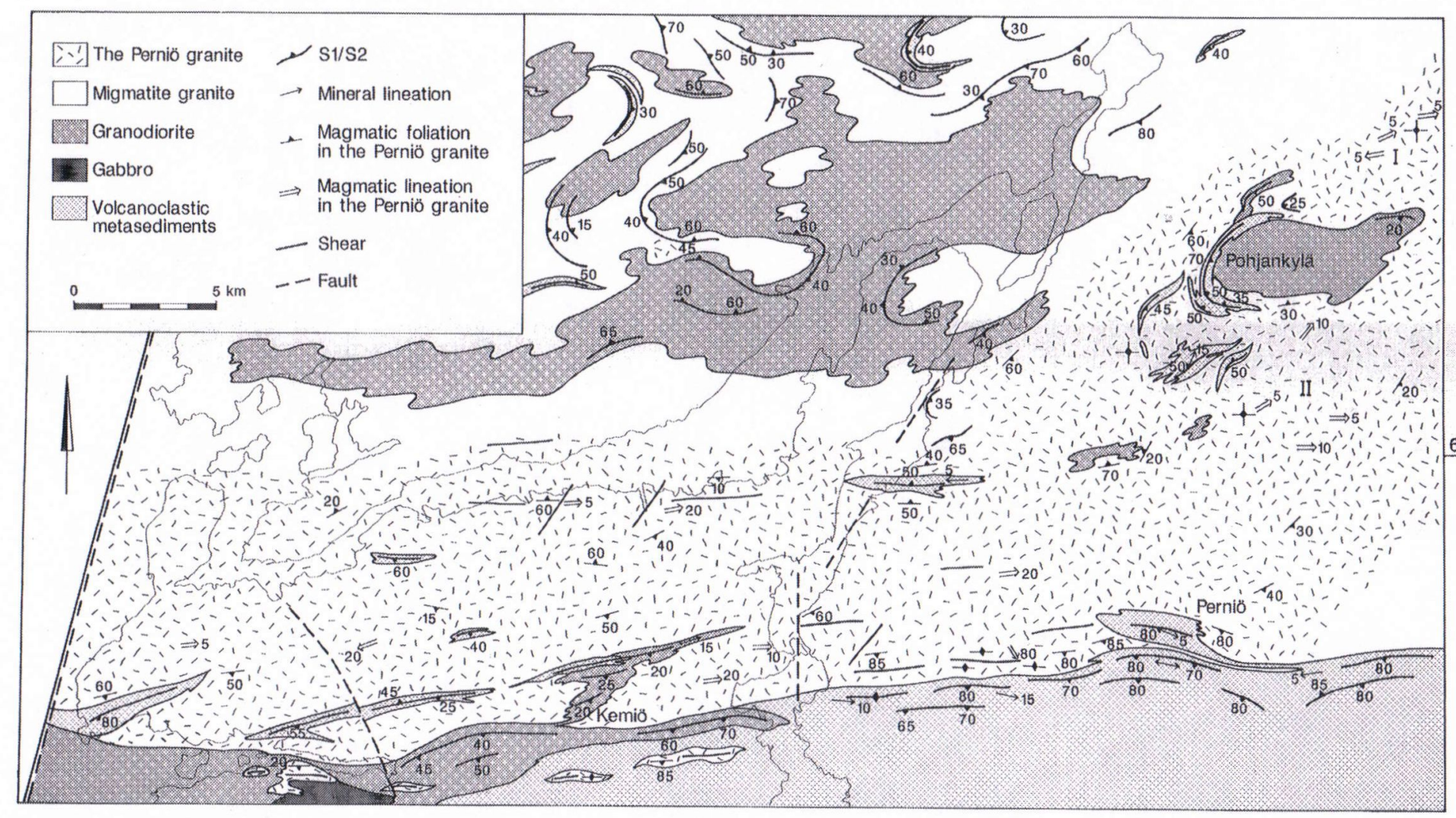

Figure 2. Structural map of the Perniö granite sheet. S1/S2 includes the S1/S2 schistosity in the supracrustals and in the restites in the migmatite granite, and the $S 2$ foliation in the granodiorites. The structures are based on observations by the authors. The lithology is based on observations by the authors and on Seitsaari (1955), Lehijärvi (1957), Edelman (1985), Lindberg et al. (1994) and Lindroos et al. (1996). 


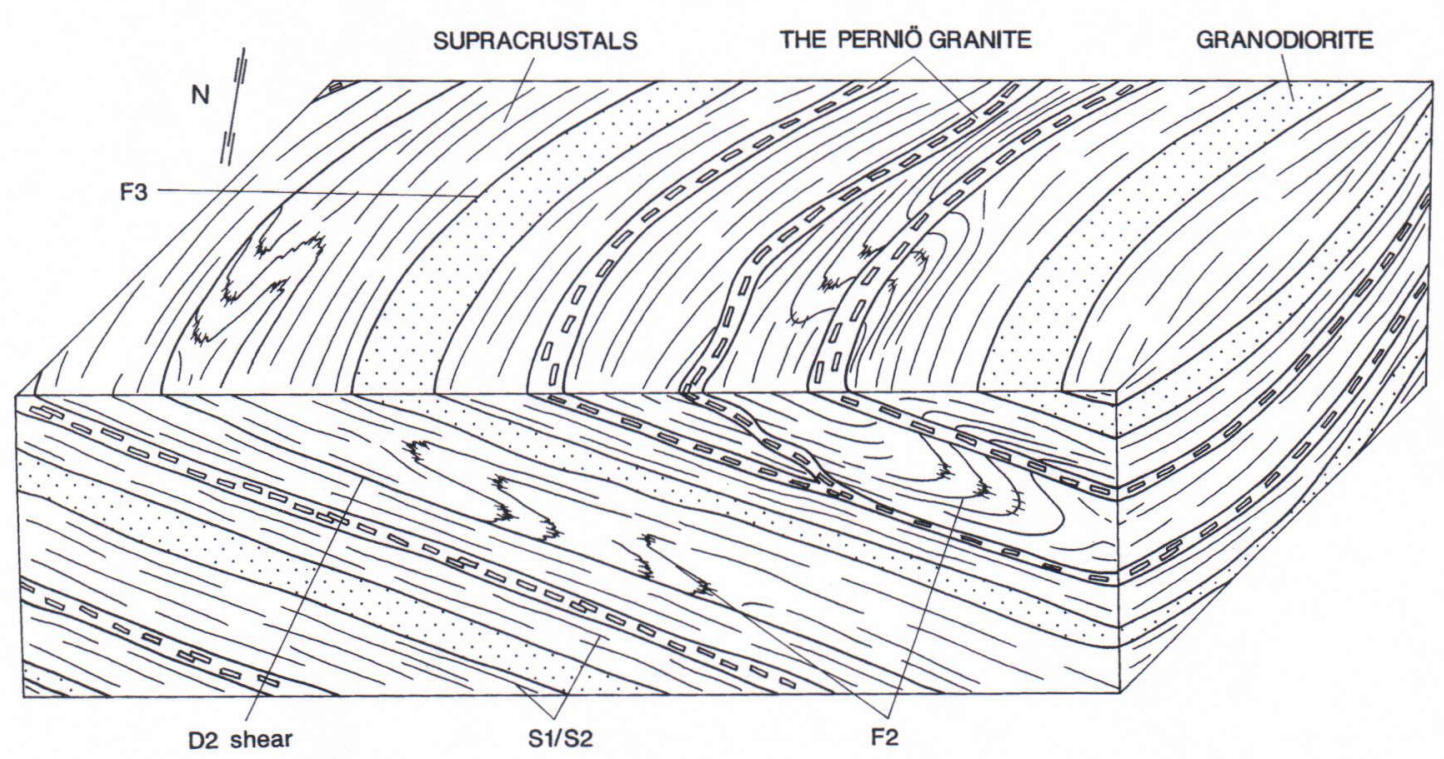

Figure 3. An illustration of the structural sequence in Pohjankylä in the Perniö area (see Fig. 2 for location). The illustration is based on interpretation of the structures in the hinge of a F3 fold. Not to scale.

The F2 folds are tight, recumbent and mainly overturned towards the NNW with north-northwesterly vergences and gently dipping axial planes (Fig. 3). The fold axes plunge gently towards the ENE. Some of the F2 folds are associated with gently dipping D2 shear zones (Fig. 3). The F2 folds are often confined to distinct layers, such as marbles. No regional scale F2 folds have been observed in this area. Crenulation cleavage defines new axial plane schistosity in some F2 folds (Fig. 3). The main schistosity in the supracrustals is therefore labelled as S1/S2, which is a composite schistosity. F2 folds can be observed eg. in Pohjankylä (Fig. 2) and in the northwestern part of the Perniö area.

The regional F3 folds (F2 in Ehlers et al. 1993) are roughly co-axial with the F2 folds, they are upright and transpose earlier structural elements parallel to the east-west trending F3 axial planes (Fig. 1 and 2). The F3 folds are mostly open and the axial planes are steep, striking $\mathrm{N} 60^{\circ} \mathrm{E}-\mathrm{N} 90^{\circ} \mathrm{E}$. The $\mathrm{F} 3$ fold axes plunge gently $\left(0-30^{\circ}\right)$ both ways in the E-W direction producing dome and basin interference structures often observed as crescent-shaped inclusions of supracrustal layers in the infracrustals (Fig. 1 and 2). No new axial plane schistosity is formed during the D3 deformation. The mineral lineation (L2/L3) is roughly parallel to the gently dipping F3 fold axes.

\section{Structures in the Perniö granite}

A penetrative foliation in the Perniö granite is formed by the preferred orientation of potassium feldspar phenocrysts. The prevailing regional trend of this orientation is east-west in the Kemiö area curving towards ca $\mathrm{N} 60^{\circ} \mathrm{E}$ in the Perniö area (Fig. 2). The dip of the foliation is generally subhorizontal turning steep close to the southern contact (Fig. 2), indicating a sheet-like "tongue" structure for the Perniö granite. In outcrops the intensity of the foliation varies and the granite can be massive and seemingly undeformed. On foliation planes a subhorizontal lineation defined 


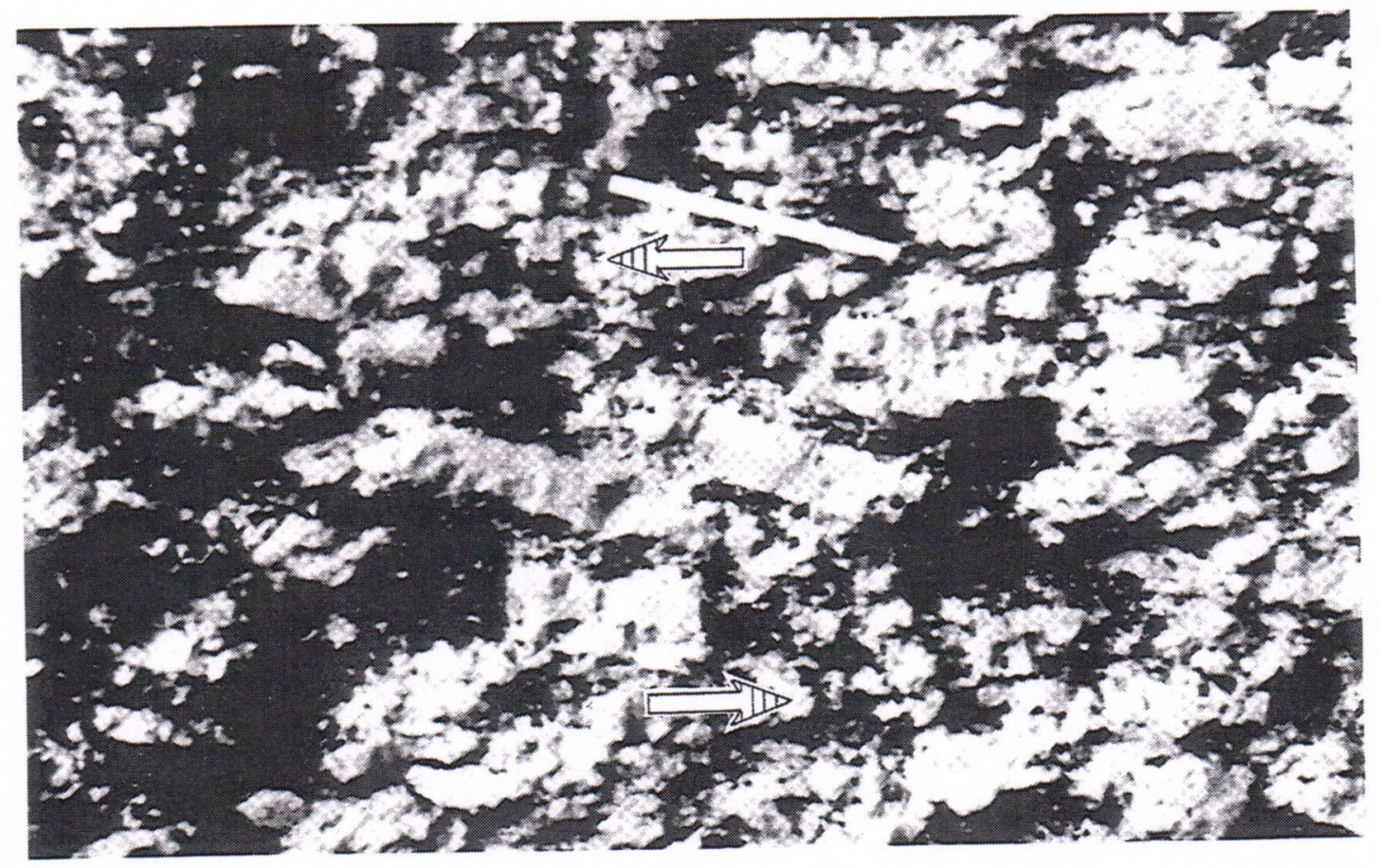

Figure 4. Imbrication of potassium feldspar phenocrysts in the porphyritic Perniö granite on a vertical outcrop, indicating horizontal rotation of the phenocrysts. The sense of rotation is shown (top towards the west). See the $4,5 \mathrm{~cm}$ long match for scale. Central parts of the Perniö area (II in Fig. 2).

by the orientation of the long axes of potassium feldspar phenocrysts can be observed. The lineation dips gently mainly eastwards all over the Perniö granite, except for the southern contact area, where it is steep (Fig. 2).

An imbrication of the potassium feldspar phenocrysts can be discerned in the Perniö granite in vertical outcrops parallel to the subhorizontal lineation and perpendicular to the foliation $(\mathrm{XZ}$ section of the strain ellipsoid) (Fig. 4).

The Perniö granite partly cuts and is partly conformal with the open and upright F3 folds (Fig. 3). In the F3 fold in Pohjankylä, it intrudes in a step-like manner, jumping from layer to layer over the S1/S2 schistosity (Fig. 3). The granite has often used the earlier gently dipping D2 shear zones and F2 axial planes as conduits for intrusion (Fig. 3). In the F3 fold hinge in Pohjankylä, the earliest pulses of the granite exhibit an S3 foliation.

\section{Shear and fault zones}

Ductile E-W striking subvertical shear zones occur in the Perniö granite (Fig. 2). The zones exhibit a dextral sense of lateral shear defined by the asymmetry of the K-feldspar phenocrysts. In the schists of Pohjankylä, dykes of the Perniö granite are drawn out to E-W directed boudins. The Perniö granite is cut by local NNE-SSW trending ductile subvertical shear zones (Fig. 2) showing a sinistral sense of lateral shear indicated by the rotation of the foliation. Occasionally the same direction is associated with sinistral left-lateral brittle deformation.

To the south of the southern contact of the Perniö granite in the Kemiö area, an over $10 \mathrm{~km}$ long dyke of sheared porphyritic Perniö granite can be found in an E-W direction (augengneiss of Verhoef \& Dietvorst 1980, microcline augen mylonite of Lindroos et al. 1996) (Fig. 2). The 
dyke granite is richer in biotite, and the potassium feldspar phenocrysts are smaller than in an average Perniö granite. The dyke is located in an older, subvertical pre-granite shear zone with a steeply dipping streching lineation. The dyke is typically discontinuous forming a band of magma filled jogs which tapers out and disappears in the surrounding shear zone. In the east the dyke is narrow $(5-50 \mathrm{~m})$ and dips steeply $\left(80-90^{\circ}\right)$ towards the south (Fig. 2). Westwards it bends over northwards showing areally larger exposure (ca $0,5 \mathrm{~km}$ in width) dipping gently $\left(20-40^{\circ}\right)$ towards the south (Fig. 2 ). The granite in the dyke exhibits a dextral sense of lateral shear defined by the asymmetry of the K-feldspar phenocrysts.

The western contact of the Perniö granite is marked by a major NNE-SSW striking steeply dipping regional shear zone (Fig. 2). In the northwestern parts of the Sauvo-Perniö granite area, the shear zone shows a subvertical ductile west-side-up sense of shear defined by the rotation of the foliation, while in the western part of the Kemiö area the zone exhibits a brittle left-lateral strike-slip sense of movement in N-S direction. To the east of the regional shear zone in the Kemiö area, a brittle right-lateral fault zone in NW-SE direction cuts both the Perniö granite and the host rocks (Fig. 2).

Narrow, N-S directed steeply dipping fault zones occur in the Perniö granite along the boundary between the Kemiö and Perniö areas (Fig. 2).

\section{STRUCTURAL ANALYSIS AND EMPLACEMENT OF THE PERNIÖ GRANITE}

\section{The older gneisses}

The F1 folds are sparse in the area. Schreurs \& Westra (1986), Bleeker \& Westra (1987) and Ploegsma \& Westra (1990) describe F1 folds similar to those in this paper. According to them the F1 folds are produced by a thrust-related subhorizontal D1 deformation.
The D2 deformation as defined in this study is characterized by recumbent folds with NNW vergences. The recumbent style of the F2 folds along specific layers and the associated D2 shear zones, indicate thrusting towards the NNW during the D2 deformation. During the D3 deformation the previously formed subhorizontal structures are folded to more upright positions. The F3 axial planes strike ENE-WSW and dip steeply suggesting a NNW-SSE compressional tectonism during the D3 deformation.

\section{The Perniö granite}

The sheet-like structure of the Perniö granite (Fig. 5) is indicated in several ways. The magmatic foliation and lineation in the granite vary from steep in the southern parts to gently dipping in the north. The steep dip along the southern contact indicates that the granite sheet disappears under the supracrustal rocks or steepens into a subvertical dyke similar to the one south of the granite. Subhorizontal contacts between the Perniö granite and the supracrustals are exposed in the Kemiö area not far from the southern contact. The change of dip from flat to steep is thus rather abrupt along the southern margin, which represents the root zone of a granite as defined by Vigneresse (1995). Supracrustal rocks are exposed in topographical depressions in the Kemiö area giving the impression of being windows in a rather thin sheet of granite. It is possible that the granite forms several thin sheets in different etages along suitable subhorizontal surfaces in the gneisses and that we can observe only some of them because the present low relief peneplane has the same direction. The Perniö granite is more homogeneous and areally larger in the Perniö area than in the Kemiö area. This could indicate exposure of slightly different vertical levels of the crust (east-side-up). However, no major shear zone seems to separate the areas. The two areas could represent two different sheets (pulses) of magma at slightly different 


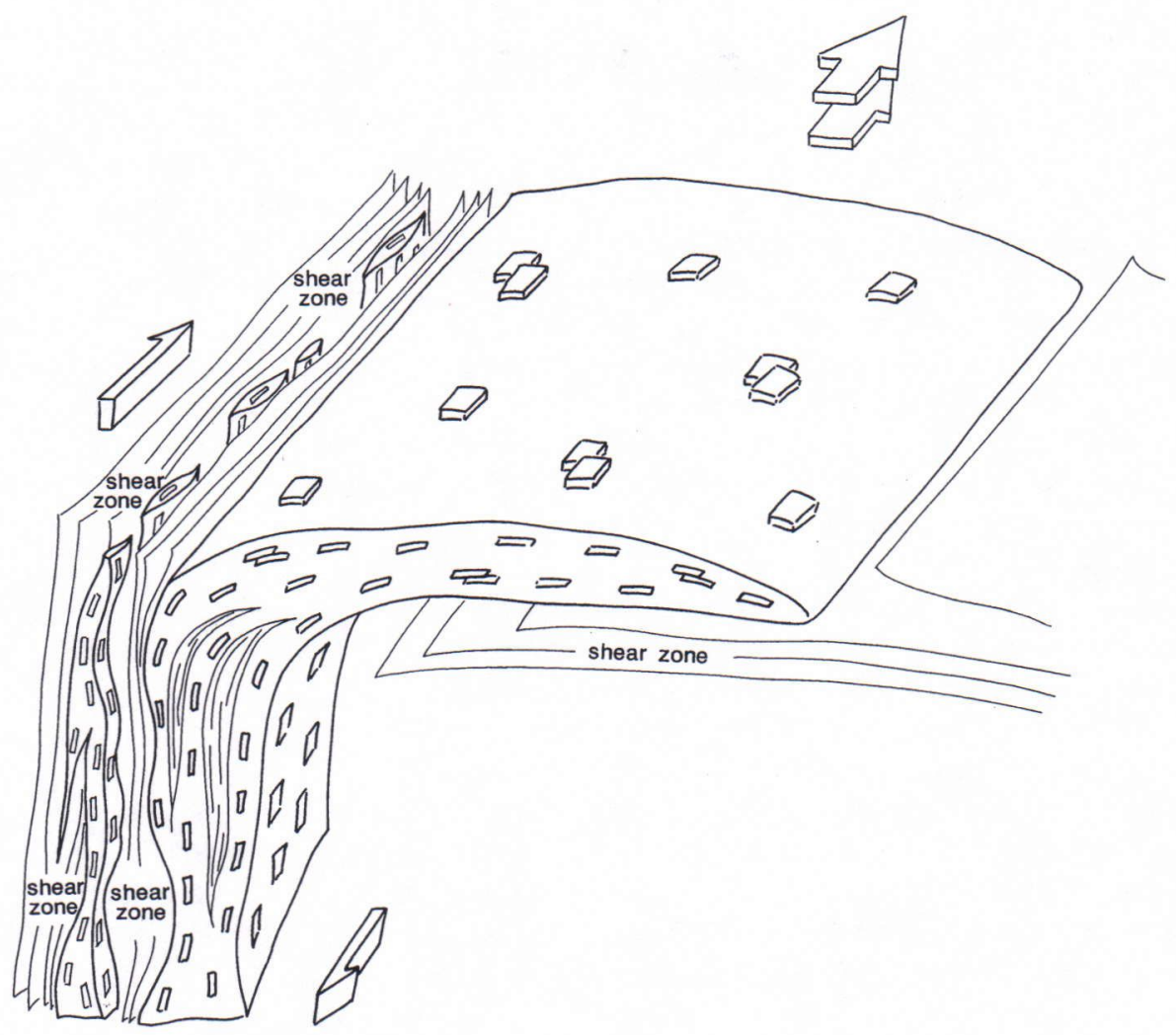

Figure 5. A schematic model for the structure and the emplacement of the Pernio granite sheet. The granite was injected into active subvertical mid-crustal shear zones operating as feeder channelways. The granite probably ascended by a strike-slip dilatancy pumping mechanism (D'Lemos et al. 1992; Brown 1994) in the anastomosing shear zones. The emplacement was also controlled by active subhorizontal shears, which performed as final loci for the magmas and produced the imbrications of the $K$-feldspar phenocrysts (Fig. 4) in the granite. The sense of movement of the roof of the granite is towards the west. See text for further explanation. A view towards the west. Not to scale.

levels or sheets with different thicknesses, or steps in the magma sheet.

The euhedral potassium feldspar phenocrysts in the Perniö granite are frequently imbricated as tiles on a roof (tiling), forming a magmatic lineation in the granite. The tiling of phenocrysts indicates non-coaxial deformation in a viscous materia and involves rotation of the phenocrysts, and deformation of rock in a magmatic state (Den Tex 1969; Blumenfeld 1983; Blumenfeld \& Bouchez 1988; Paterson et al. 1989; Ildefonse et al. 1992a; Ildefonse et al. 1992b; Nicolas
1992). The sense of rotated phenocrysts and groups of phenocrysts has been measured in the Perniö granite (mainly in the Perniö area) on vertical outcrops parallel to the E-W directed lineation. The best areas for measurements were the parts of the Perniö granite with the most subhorizontal foliation, but observations on imbrications were possible all over the area. 60,9 $\%$ of the observations $(n=87)$ in the northern parts of the Perniö area (I in Fig. 2), 76,4 \% of the observations $(n=110)$ in the central parts (II in Fig. 2) and a total of $70,8 \%$ of all the 
observations $(n=228)$ indicate a sense of movement of the top of the Perniö granite sheet towards the west (see also Ehlers et al. 1993). The direction of the movements is consistent all over the Perniö granite. The tiling of the $\mathrm{K}$-feldspar phenocrysts in the Perniö granite thus shows that the granite was syn-intrusively deformed in the magmatic state in a subhorizontal non-coaxial tectonic regime with a direction of movement of the roof the granite sheet towards the west. The solid state deformation in the granite was mainly concentrated to ductile shears and brittle faults.

The partly discordant partly concordant behaviour of the Perniö granite with respect to the F3 folds shows that the granite intruded during a late stage of the F3 folding. The emplacement was controlled by both subvertical and subhorizontal shear zones (Fig. 5). Along the southern margin of the granite there is an E-W trending subvertical pre-granite shear zone. The subvertical sheared dyke of Perniö granite in the Kemiö area has intruded into the same shear zone. As indicated by the structural sequence in Pohjankylä and by the sheared subhorizontal footwall contact between the supracrustals and the Perniö granite, the emplacement of the granite was also controlled by the gently dipping, during D3 reactivated or still active, earlier (D2) shear zones (and the F3-folded F2 axial planes). These shears provided non-coaxially deforming zones of weakness for the intrusions and produced the imbrication of the $\mathrm{K}$-feldspar phenocrysts in the Perniö granite.

The tiling of the potassium feldspar phenocrysts, the tectonic control of the intrusion of the granite and the timing of the intrusion of the granite to the late F3 folding suggest that an E-W trending shearing and a NNW-SSE directed F3 compression acted contemporaneously during the emplacement of the Perniö granite. This defines a transpressional tectonic regime during the D3 bringing about a combination of subvertical and subhorizontal shears in the mid-crust operating as transporting channels and final loci for the granitic magmas as suggested by Ehlers et al. (1993). The E-W shearing has outlasted the NNW-SSE folding as seen in the consistent tiling of the phenocrysts and in the E-W trending shear zones in the Perniö granite.

The western contact of the Perniö granite is marked by a regional NNE-SSW trending steeply dipping shear and fault zone. The zone has recorded a long history of shearing and faulting, starting with a ductile west-side-up movement. The tectonic movements have continued in the brittle state (see also Fjäder 1991; Lindroos et al. 1996). The shear zone separates lithologies with different metamorphic grades (higher grade on the western side) at the present level of erosion (cf. Lindroos et al. 1990). The structures in the zone indicate subvertical tectonic movements, which have commenced soon after the emplacement of the Perniö granite. Lindroos et al. (1996) argue that the transpressional tectonism has persisted some 30-40 Ma after the emplacement of the Perniö granite as shown by the deformation of ca 1800 Ma old pegmatites a few kilometres south of the Perniö granite. The regional steeply dipping shear and fault zone bordering the Perniö granite may have begun to form during the later stages of the transpressional tectonics indicating the commencement of orogenic collapse, where the transpressional tectonics was followed by crustal extension as proposed by i.a. Lahtinen (1994), Väisänen et al. (1994) and Korja (1995).

The geometry of the Perniö granite dyke within the sheared rocks south of the Perniö granite sheet suggests a mechanism for the ascent of the magma in the crust and the emplacement of the granite (Fig. 5). The dyke is composed of large (several hundred metres long) jogs of granite separated by sections where the dyke has been sheared out completely. This could be indicative of strike-slip dilatancy pumping as described by D'Lemos et al. (1992) and Brown (1994). The transport of magma is driven by alternating compression and dilatation in the anastomosing shear zone. The extensional parts of the shear zones are filled with magma which during the subsequent compression is squeezed upwards into overlying diladant 
cavities in the zone. The upward pumping effect is aided by the force of buoyancy. The integrated model of D'Lemos et al. (1992) and Brown (1994) involves an inversion of a sedimentary basin in a transpressional setting - a geological environment suggested for the southern coast of Finland by Ehlers et al. (1993).

\section{CONCLUSIONS}

The 1840-1830 Ma old porphyritic Perniö granite intruded during the late F3 folding along subvertical and subhorizontal shear zones. Granite dykes were injected into active steep shear zones acting as feeder channels in a mid-crustal setting. The granite was finally emplaced as one or more sheets along active gently dipping shear zones. The granite was deformed in magmatic state as the $\mathrm{K}$-feldspar phenocrysts in the granite sheet were imbricated in response to tectonic movements along the subhorizontal shear zones. The sense of movement of the top of the granite sheet is consistently towards the west. A possible intrusion mechanism for the Perniö granite could have been strike-slip dilatancy pumping along the subvertical shear zones in a regional transpressional setting.

ACKNOWLEDGEMENTS: This work is a part of our studies on dimension stone geology of southern Finland financed by the K.H. Renlund Foundation. Synnöve Hollsten mapped parts of the northwestern part of the Sauvo-Perniö granite area structurally. Tua Welin assisted in preparing some of the figures and the final drafting of the line drawings was made by Merja Kuusisto. The thin sections were prepared by Veikko Grönroos. Bo Lindberg and Kenneth Fjäder gave profound and critical comments on the manuscript. The English was checked by Paula Harju. The contributions are gratefully acknowledged. 


\section{REFERENCES}

Bleeker, W. and Westra, L. 1987. The evolution of the Mustio gneiss dome, Svecofennides of SW Finland. Precambrian Res., 36, 227-240.

Blumenfeld, P. 1983. Le "tuilage des mégacristaux", un critére d'écoulement rotationnel pour les fluidalités des roches magmatiques. Application au granite de Barbey-Séroux (Vosges, France). Bull. Soc. géol. Fr. 7 Ser. XXV, 309-318.

Blumenfeld, P. and Bouchez, J.-L. 1988. Shear criteria in granite and migmatite deformed in the magmatic and solid states. J. Struct. Geol. 10, 361-372.

Brown, M. 1994. The generation, segregation, ascent and emplacement of granite magma: the migmatite-to-crustally-derived granite connection in thickened orogens. Earth-Sci. Rev. 36, 83-130.

Den Tex, E. 1969. Origin of ultramafic rocks, their tectonic setting and history. Tectonophysics 7, 457-488.

D'Lemos, R.S., Brown, M. \& Strachan, R.A. 1992. Granite magma generation, ascent and emplacement within a transpressional orogen. J. Geol. Soc. London. 149, 287-490.

Edelman, N. 1985. Pre-Quaternary rocks of the Nauvo (Nagu) map-sheet area. Geological map of Finland 1:100 000. Explanation to the maps of Pre-Quaternary rocks, sheet 1034 Nagu. Geological Survey of Finland. 47 pp. (In Finnish with an English summary).

Ehlers, C., Lindroos, A. and Selonen, O. 1993. The late Svecofennian granite-migmatite zone of southern Finland - a belt of transpressive deformation and granite emplacement. Precambrian Res., 64, 295-309.

Eskola, P. 1914. On the petrology of the Orijärvi region in southwestern Finland. Bull. Comm. Géol. Finlande, 40. 277 pp.

Fjäder, K. 1991. Stratigrafi och tektonik hos Proterozoiska suprakrustala bergarter i Pargas, SW Finland. (Stratigraphy and tectonics of Proterozoic supracrustal rocks in Pargas, SW Finland). Unpublished M. Sc. thesis. Åbo Akademi University. Department of geology och mineralogy. Turku. 63 pp. (In Swedish).

Härme, M. 1960. The general geological map of Finland 1:400 000. Sheet B 1 Turku. Explanation to the maps of rocks. Geological Survey of Finland. Helsinki. 78 pp. (In Finnish with an English summary).
Hölttä, P. 1986. Observations of the metamorphic reactions and PT conditions in the Turku granulite area. Geol. Surv. Finland, Bull. 339, 43-58.

Ildefonse, B., Sokoutis, D. and Mancktelow, N.S. 1992a. Mechanical interactions between rigid particles in a deforming ductile matrix. Analogue experiments in simple shear flow. J. Struct. Geol. $14,1253-1266$.

Ildefonse, B., Launeau, P., Bouchez, J.-L. and Fernandez, A. 1992b. Effect of mechanical interactions on the development of shape preferred orientations: a two-dimensional experimental approach. J. Struct. Geol. 14, 73-83.

Korja, A. 1995. Structure of the Svecofennian crust - growth and destruction of the Svecofennian orogen. Institute of seismology, University of Helsinki, Report S-31. 36 pp.

Lahtinen, R. 1994. Crustal evolution of the Svecofennian and Karelian domains during 2.1-1.79 Ga, with special emphasis on the the geochemistry and origin of 1.93-1.91 Ga gneissic tonalites and associated supracrustal rocks in the Rautalampi area, central Finland. Geol. Surv. Finland, Bull. 378, $128 \mathrm{pp}$.

Lehijärvi, M. 1957. Geological map of Finland 1:100 000. Pre-Quaternary rocks. Sheet 2021 Salo. Explanation to the map of rocks. Geological Survey of Finland. Helsinki. 30 pp. (In Finnish with an English summary).

Lindberg, B., Ehlers, C. and Edén, P. 1994. Geological map of Finland. Pre-Quaternary rocks. 1:100 000. Sheet 1043 Turku. Geological Survey of Finland. Espoo.

Lindroos, A., Ehlers, C. and Åberg, G. 1990. A Rb-Sr whole-rock isochron of $1.5 \mathrm{Ga}$ in early Proterozoic pillow lavas in SW Finland. Geol. Fören. Stockholm Förh. 112, 51-58.

Lindroos, A., Romer, R.L., Ehlers, C. and Alviola, R. 1996. Late-orogenic Svecofennian deformation in SW Finland constrained by pegmatite emplacement ages. Terra Nova 8, 567-574.

Nicolas, A. 1992. Kinematics in magmatic rocks with special reference to gabbros. J. Petrology 33, 891915.

Paterson, S.R., Vernon, R.H. and Tobisch, O.T. 1989. A review of criteria for the identification of magmatic and tectonic foliations in granitoids. J. Struct. Geol. 11, 349-363.

Ploegsma, M. and Westra, L. 1990. The early Proterozoic Orijärvi triangel, (southwest Finland). A key area on the tectonic evolution of the Svecofennides. Precambrian Res. 47, 51-69. 
Schreurs, J. 1985. Prograde metamorphism of metapelites, garnet-biotite thermometry and prograde changes of biotite chemistry in high-grade rocks of West Uusimaa, southwest Finland. Lithos 18, 69-80.

Schreurs, J. and Westra, L. 1986. The thermotectonic evolution of a Proterozoic, low pressure, granulite dome, West Uusimaa, SW Finland. Contrib. Mineral. Petrol. 93, 236-250.

Seitsaari, J. 1955. Geological map of Finland 1:100 000. Pre-Quaternary rocks. Sheet 2012 Perniö. Geological Survey of Finland. Helsinki.

Selonen, O. 1994. Granittektonik och prospektering av byggnadssten - exempel från södra Finland. (Granite tectonics and exploration for dimension stone - examples from southern Finland). Unpublished Ph. Lic. thesis. Åbo Akademi University. Department of geology and mineralogy. Turku. 122 pp. (In Swedish).

Simonen, A. 1980. The Precambrian of Finland. Geol. Surv. Finland, Bull. 304. 58 pp.
Suominen, V. 1991. The chronostratigraphy of southwestern Finland with special reference to Postjotnian and Subjotnian diabases. Geol. Surv. Finland, Bull. 356, 100 pp.

Väisänen, M., Hölttä, P., Rastas, J., Korja, A. and Heikkinen, P. 1994. Deformation, metamorphism and the deep structure of the crust in the Turku area, southwestern Finland. Geol. Surv. Finland, Guide 37, 35-41.

Van Duin, J.A. 1992. The Turku granulite area, SW Finland: a fluid-absent Svecofennian granulite occurrence. $\mathrm{Ph}$. D. thesis. Department of Petrology and Isotope geology. Institute of Earth Sciences, Vrije Universiteit. Amsterdam. 234 pp.

Verhoef, P.N.W. and Dietvorst, E.J.L. 1980. Structural analysis of differentiated schists and gneisses in the Taalintehdas area, Kemiö island, southwest Finland. Bull. Geol. Soc. Finland 52, 147-164.

Vigneresse, J.L. 1995. Control of granite emplacement by regional deformation. Tectonophysics 249 , 173-186. 